\title{
NEOLIBERALISM
}

\& NEO-JIHADISM

PROPAGANDA AND FINANCE

IN AL QAEDA AND ISLAMIC STATE

\section{IMOGEN RICHARDS}

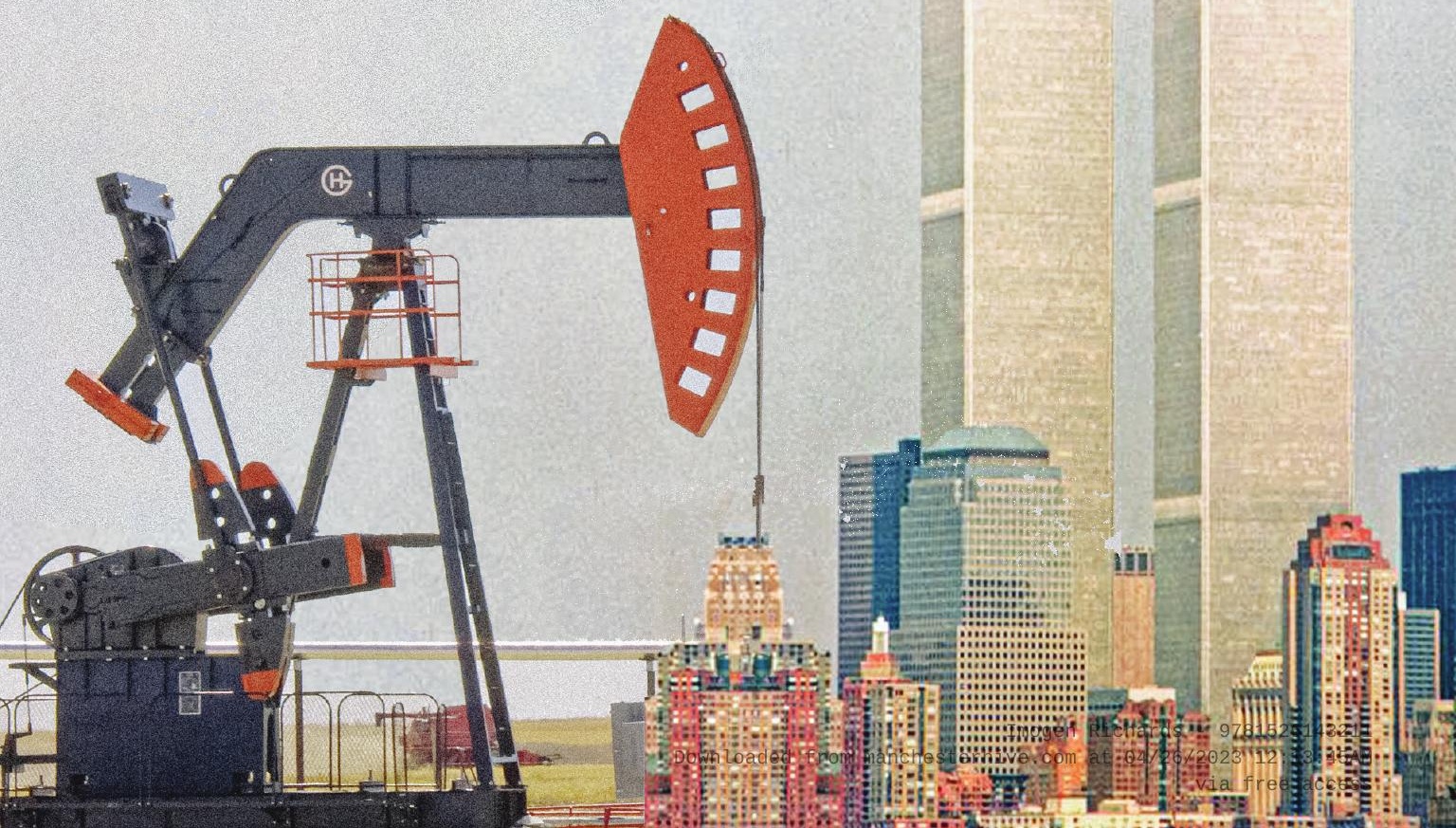




\section{Neoliberalism and neo-jihadism}

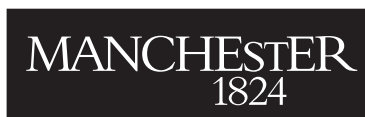

Manchester University Press 
Imogen Richards - 9781526143211 Downloaded from manchesterhive.com at $04 / 26 / 2023$ 12:13:45AM via free access 


\section{Neoliberalism and neo-jihadism \\ Propaganda and finance in Al Qaeda and Islamic State}

\section{IMOGEN RICHARDS}

Manchester University Press 
Copyright () Imogen Richards 2020

The right of Imogen Richards to be identified as the author of this work has been asserted by her in accordance with the Copyright, Designs and Patents Act 1988.

Published by Manchester University Press

Altrincham Street, Manchester M1 7JA

www.manchesteruniversitypress.co.uk

British Library Cataloguing-in-Publication Data

A catalogue record for this book is available from the British Library

ISBN 9781526143204 hardback

First published 2020

The publisher has no responsibility for the persistence or accuracy of URLs for any external or third-party internet websites referred to in this book, and does not guarantee that any content on such websites is, or will remain, accurate or appropriate.

Typeset by Sunrise Setting, Brixham 